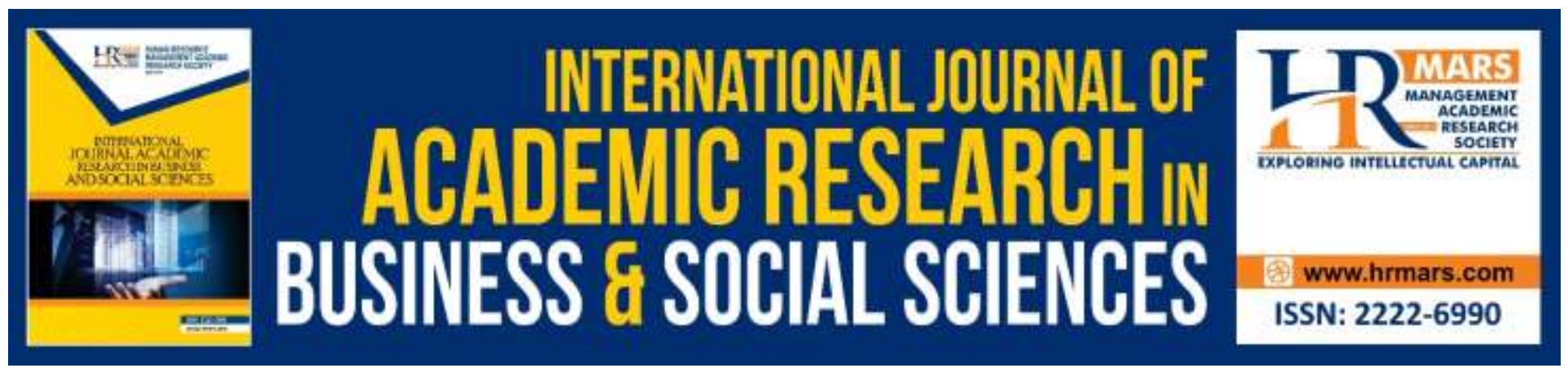

\title{
The Comparison between the Foundation of Akidah of Muhammad Ibn Abdul Wahhab and Al-Salaf Al-Soleh: The Research from the Understanding of Akidah Tawhid
}

Aminudin Basir @ Ahmad, Akila Mamat

To Link this Article: http://dx.doi.org/10.6007/IJARBSS/v8-i11/4976

DOI:10.6007/IJARBSS/v8-i11/4976

Received: 08 Oct 2018, Revised: 13 Nov 2018, Accepted: 16 Nov 2018

Published Online: 28 Nov 2018

In-Text Citation: (Ahmad \& Mamat, 2018)

To Cite this Article: Ahmad, A. B. @, \& Mamat, A. (2018). The Comparison between the Foundation of Akidah of Muhammad Ibn Abdul Wahhab and Al-Salaf Al-Soleh: The Research from the Understanding of Akidah Tawhid. International Journal of Academic Research in Business and Social Sciences, 8(11), 983-1000.

Copyright: (C) 2018 The Author(s)

Published by Human Resource Management Academic Research Society (www.hrmars.com)

This article is published under the Creative Commons Attribution (CC BY 4.0) license. Anyone may reproduce, distribute, translate and create derivative works of this article (for both commercial and non-commercial purposes), subject to full attribution to the original publication and authors. The full terms of this license may be seen at: $\underline{\text { http://creativecommons.org/licences/by/4.0/legalcode }}$

Vol. 8, No. 11, 2018, Pg. 983 - 1000

http://hrmars.com/index.php/pages/detail/IJARBSS

JOURNAL HOMEPAGE

Full Terms \& Conditions of access and use can be found at http://hrmars.com/index.php/pages/detail/publication-ethics 


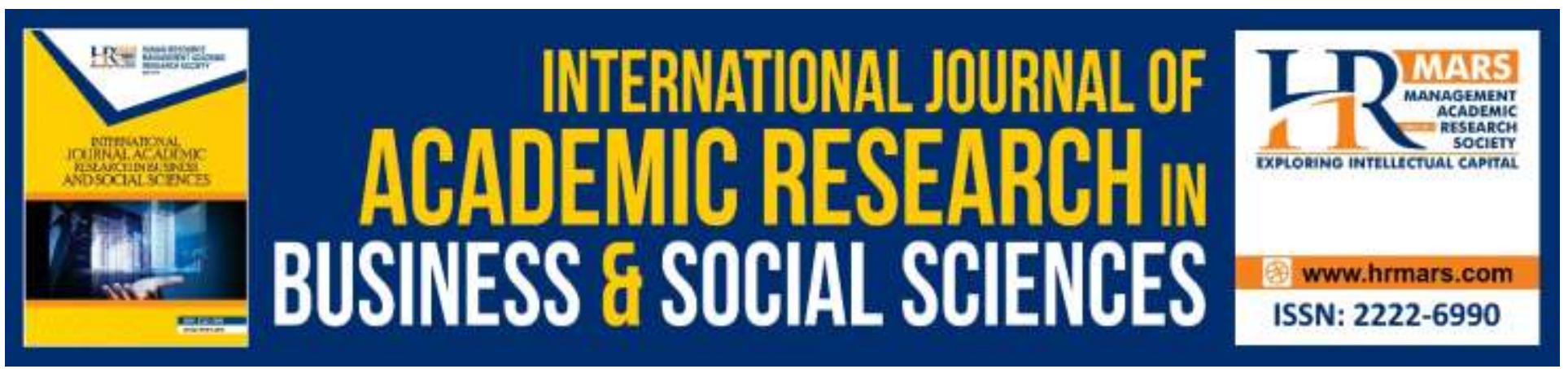

\title{
The Comparison between the Foundation of Akidah of Muhammad Ibn Abdul Wahhab and Al-Salaf Al-Soleh: The Research from the Understanding of Akidah Tawhid
}

\author{
Aminudin Basir @ Ahmad \\ Pusat Citra Universiti, Universiti Kebangsaan Malaysia,43600 UKM Bangi, Selangor Darul Ehsan \\ Malaysia, Felo Bersekutu Institut Islam Hadhari, Universiti Kebangsaan Malaysia \\ Email:manhaj@ukm.edu.my \\ Akila Mamat \\ Universiti Sultan Zainal Abidin (UniSZA), Kampus Gong Badak,21300, Kuala Nerus, Terengganu, \\ Malaysia \\ Email: akila@unisza.edu.my
}

\begin{abstract}
Akidah teaching of Muhamad Abdul Wahab or wahabiy that has been spread in Malaysia caught the attention form government and non-government as well as other organizations. Although JAKIM through the research from the Committee Review of Faith, JAPAS dan JAPIS did not stated the Wahabiy teaching as as deviant and against Ahli Sunnah Wal Jamaah. But for those who believe in akidah teaching of Abu al-Hasan al-Asya'ari or best known as the twenty attributes of Allah (sifat 20) believed that wahabiy akidah is a heresy. Those who believed in the akidah brought by Muhammad Abdul Wahab or wahabiy agreed that it is true and meet the requirements of akidah belong to alSalaf. There are obvious disputes between both parties in defending each other's akidah. The more worrying part is that, wahabi teaching was associated with the terrorist. The question is either the foundation akidah of Muhamad Abdul Wahab really gone astray from the teaching of Ahli Sunnah not? Is it true that this is parallel to the akidah of al-Salaf al-Soleh? Hence, this research is essential to find out whether or not the akidah of Muhammad Abdul Wahab atau Wahabiy meet the foundation of akidah practiced by al-Salaf al-Soleh. The finding based on this research found that Muhammad Ibn Abdul Wahhab possessed the foundation of akidah which took al-Quran and alSunnah as its main reference. The findings as well showed that his policy is match with the foundation of akidah belongs to al-Salaf al-Soleh or Ahli Sunnah Wal Jamaah. This research contributed to the
\end{abstract}


affirmation about the truth of Muhammad Ibn Abdul Wahhab's foundation of akidah. It then strengthen the stand of JAKIM that admit the truth of his akidah although there are few groups of people still consider the akidah of Muhammad Ibn Abdul Wahhab as a foundation that has gone astray.

Keywords: Faith, Muhammad Ibn Abdul Wahhab, Tauhid, al-Salaf al-Soleh

\section{Introduction}

Muhammad Ibn Abdul Wahab was assumed as a reformist that trying to purify the faith of Islamic followers and eliminates them form any elements of shirk. The faith that has been introduced by him is purely based on al-Quran and al-Sunnah. However, there are some opinions from certain parties claimed that it is wrong and contrary to the belief of the Al Sunnah Wal Jamaah members. They also claimed that his deviancy is not only in the faith of oneness of Allah (tauhid) matters but also involve things such as the islamic mysticism stuff, other belief such as tawassul matters, problems in takfir and so on Hence, they called the preaching of Muhammad Ibn Abdul Wahab as Wahabi which is an insult and it symbolizes heresy. The opposition towards his teaching by Muslims can be found in few countries like Pakistan, Egypt, Jordan, Yemen, Indonesia, Thailand as well as in Malaysia.

There are also many articles, magazines as well as books written to claim about the error against the teachings of the Faith fought by him. In the meantime, there are also writings published and distributed to defend the truth of the teaching brought by him.

In Malaysia, the teaching of Muhammad Ibn Abdul Wahab also known as the teaching of the youth. This is because it was found to be contradicting with the teaching of the teachers in islamic school during the old days which considered as the teaching for elderly. Until now, the youth is still believed to hold on to the wrong. In academic perspectives, the Malaysia students of Islamic studies from alAzhar University in Egypt are generally possess the different doctrine of faith with the Malaysian graduate from other Islamic universities such as Madinah, Ummul Qura dan Riyad. Usually, graduate from Egypt will be assumed as people who support the akidah teaching of Muhammad Ibn Abdul Wahab which totally different from the akidah of al-Azhar graduates. This conflict was widespread up to the university which involved the academicians and knowledgeable people. Lately, this dispute seems to be more serious when there are some authorities that brought these things to the court level in order to solve the problem legally according to law.

Hence, based on the problem aroused, the researcher feels that it is necessary to conduct a research to analyze the foundation of akidah tauhid hold by Muhammad Ibn Abdul Wahab. As the benchmark to his faith, the researcher will analyze the foundation of akidah belongs to al-Salaf al-Soleh as the base to evaluate the position of tauhid brought by Muhammad Ibn Abdul Wahab.

\section{Research Objective}

The purpose of this research is to identify and analyses the foundation of faith of Muhammad Ibn Abdul Wahhab. This study will as well analyses the foundation of faith of al-Salaf al-Soleh's group. Last but not least this research aim to identify whether or not the doctrine of faith brought by Muhammad Ibn Wahhab is parallel to the doctrine of tauhid belongs to al-Salaf al-Soleh. 


\section{Research Methodology}

This research used qualitative method which happen through the analysis of related documents. The researchers will get the documents that explain about the doctrine of faith of Muhammad Ibn Abdul Wahhab. The primary source is from the documents written by Muhammad Ibn Abdul Wahhab himself. While for the secondary sources consist of the documents written by the other scholars, that clarified about the the faith of Muhammad Ibn Abdul Wahhab. The information sought was narrowed down to the foundation of his faith which is limited to three main parts of faith.

As for the foundation of al-Salaf al-Soleh, the main sources of their writing will be referred. AlSalaf here referring to two aspects which are age and methodology. From the age aspect it referred to the writing by Islamic scholars that live between the first 100 up to $300 \mathrm{Hijrah}$. While in methodology it referred to the masterpieces of Islamic scholars after $300 \mathrm{Hijrah}$ to $1206 \mathrm{Hijrah}$ which coincide with Muhammad Ibn Abdul Wahhab's date of demised. The current writings will as well be taken as reference in order to get the facts that can help to strengthen this research.

The writer will list down the foundations of faith of Muhammad Ibn Abdul Wahhab and the explanation that will be given in details. The writer will also write down the foundations of faith of the al-Salaf al-Soleh, the writer's reviews and opinion will also be submitted.

\section{Literature Review \\ Background}

His name and and his descendent is Muhammad Ibn Abdul Wahab Ibn Sulaiman Ibn Ali Ibn Muhammad Ibn Ahmad Ibn Rasyid Ibn Barid Ibn Muhammad Ibn Barid Ibn Musyrif Ibn Umar Ibn Ma'dad Ibn Rays Ibn Zakhir Ibn Muhammad Ibn Alwiy Ibn Wahib Ibn Qasim Ibn Musan Ibn Masud Ibn Uqbah Ibn Sani' Ibn Nahsyal Ibn Syaddad Ibn Zahir Ibn Syihab Ibn Rabi'ah Ibn Aswad Ibn Malik Ibn Hanzalah Ibn Malik Ibn Zaid Manat Ibn Tamim Ibn Mur Ibn Ud Ibn Tabikhah Ibn Ilyas Ibn Nudhar Ibn Nazzar Ibn Maad Ibn Adnan (al-Rudaiman 2005). He was born in $1115 \mathrm{H}$ at al-Uyaynah which located in Riyad territory, the capital of Egypt nowadays (al-Rudaiman, 2005).

He succeededd in memorizing the whole holy al-Quran before he reach 10 years old. He learned and deepen the religious knowledge like translation, hadith, fiqh, and so on from his own father, Abdul Wahhab Ibn Sulaiman which also a qadhi at Uyaynah (al-'Abud, 2006). Muhammad Ibn Abdul Wahhab migrated to few regions to understand deeper about Islam such as Hijaz, Basrah dan Ihsa'. Among his teachers are, Syekh Abdullah Ibn Ibrahim Ibn Saif, Syekh Muhammad Hayat al-Sindiy, Syekh Muhammad al-Majmu'iy al-Basriy, Syekh al-Musnad Abdullah Ibn Salim al-Basriy dan Syekh Abdul Latif al-'Afaliqiy al-Ihsa'iy are (Faryaan, 1999).

Before Muhammad Ibn Abdul Wahhab started his preach, Najd is a state that consists of few small and undevelop towns. There are always dispute and war in between that particular area. Other than a bit backwords, Najd is a place where people spreader the practice of shirk and superstitious. The same phenomenon also accured in Hijaz although the spreading of knowledge there was found to be quite intense as compared to Najd. In this situation, Allah s.w.t sent down a reformist figure which is 
known as Muhammad Ibn Abdul Wahhab in order to elimiate the shirk practices and to upright the community life based on the teaching from al-Quran dan al-Sunnah (al-Rudaiman, 2005).

Muhammad Ibn Abdul Wahhab died on 1206H, on Moday in the month of Syawal at the age of 92 years old (al-Abud, 2006). He produced numbers of superb masterpieces that touched on various kind of topics which among them are Kitab al-Tauhid, Kasyf al-Syubhaat, Usul al-Imam, Fadail alIslam, Thalathah Usul, al-Qawaid al-Arbaáh, Adab al-Masyi Ila al-Solah (al-Rudaiman, 2005:19).

\section{The Source of Faith}

Syeikh Muhammad Ibn Abdul Wahhab strongly hold onto the al-Quran dan al-Sunnah as well as ijma. He discussed things related to akidah based on the al-Quran verses and al-Sunnah. He stated that each and every individu really needs to know the teaching proposed by Rasulullah s.a.w. According to Prophet Muhammad's teaching, man will be able to know the speciality required by Allah from human being. His teaching is easy to be understood, since the words to pronounce is short and simple but contains a very deep meaning. Ibn Syihab al-Zuhri said that there are many religious matters that have been explained using the simplified language or known as Jawami'al-Kalim (al-Atram, 1991). He said that al-Quran is the kalam (words) of Allah s.w.t and it is obviously not the words from any creature. Al-Quran comes from Allah and it will certainly returns to Him. He also referred to al-Sunnah as the foundation of his doctrine of faith (al-Najdiy, 1996:30). All the explanation about the punishments and the favor in the grave, the returns of ruh to the body, questions from munkar and nankir, the bridge, hereafter, the fire, the heaven that has been explained by Rasulullah s.a.w are pure and true (al-Najdiy, 1996).

His firm belief in this matter is clearly presented in every akidah discussion he conducted. While discussing about four foundations that related to religion. The first one that is not permissible (haram) to talk about is something in the religion which have not been stated by Allah. Allah said in al-Áraf, verse 33 which means:

Meaning:" Say, "My Lord has only forbidden immoralities - what is apparent of them and what is concealed - and sin, and oppression without right, and that you associate with Allah that for which He has not sent down authority, and that you say about Allah that which you do not know."

The second policy is when there is no explanation from the religion about something, hence it can be done. It cannot simply be stated as prohibited (haram) or compulsory and also not adviseable to say it an offensive act as or voluntary. Allah said in surah al-Maidah, verse 101:

Meaning ; "Believers! Do not ask of the things which, if made manifest to you, would vex you;116 for, if you should ask about them while the Qur'an is being revealed, they will be made manifest to you. Allah has pardoned whatever happened in the past. He is All-Forgiving, All-Forbearing."

The third policy is the prohibition to practice things they are doubt about and leave what is clear. Allah s.w.t said in surah Aali Imran, verse 7: 
Meaning" It is He who has sent down to you, [O Muhammad], the Book; in it are verses [that are] precise - they are the foundation of the Book - and others unspecific. As for those in whose hearts is deviation [from truth], they will follow that of it which is unspecific, seeking discord and seeking an interpretation [suitable to them]. And no one knows its [true] interpretation except Allah. But those firm in knowledge say, "We believe in it. All [of it] is from our Lord." And no one will be reminded except those of understanding."

The fourth foundation is The lawful is clear and the prohibited is clear, and between them are unclear matters. Rasulullah s.a.w said, that the meaning is:

The halal ( lawful) is clear and the haram (prohibited) is clear, and between them are unclear matters (syubahat) that are unkown to most people. (al-Bukhariy 2000; Muslim 2000) (al-Najdiy 1996:5-6).

If we look into details of each of the foundations above, it is clear that Muhammad Ibn Abdul Wahhab strenghten his statement by using the verses of al-Quran dan al-Hadith. This thing also showed his mastery and deep understanding about the content in al-Quran and al-Hadith.

In akidah, he also holds onto ljma (agreement). This was proven when he stated that in the ijma of al-Salaf, iman is to believe with one's heart and to demonstrate in one's physical actions. (Muallafat al-Syekh 2011, 1:740).

\section{The Foundation of Faith}

According to Muhammad Ibn Abdul Wahhab, the foundation of faith consists of six elements which are believe in Allah, believe in Angels, believe in holy book, believe in messengers of Allah, believe in the day of judgemet and believe in Allah's predestination. These foudation of faith is the belief of succeeded tribes known as al-Firqah al-Najiah (al-Najdiy 1996; Usul al-Thalathah 1999). He also took out the dalil from about this foundation that has been stated by Allah s.w.t in surah al-Baqarah 1: 285 Meaning:" The Messenger (Muhammad SAW) believes in what has been sent down to him from his Lord, and (so do) the believers. Each one believes in Allah, His Angels, His Books, and His Messengers. They say, "We make no distinction between one another of His Messengers" - and they say, "We hear, and we obey. (We seek) Your Forgiveness, our Lord, and to You is the return (of all)."

The faith towards al-Qadar was mentioned by Allah in surah al-Qamar 54:49:

Meaning:" Indeed, all things We created with predestination"

All these foundation of faith is his akidah has become the gist in his preach. It can be detected in many of his writing. He also provided a hadith by Jibril related to the explanation aout the foundation of faith which is:

Meaning: "Jibril said: "Tell me what is Faith (Iman)?" 'It is that you believe in Allah and His angels and His Books and His Messengers and in the Last Day, and in qadar (fate), both in its good and in its evil aspects.' (Muslim 2000).

He firmly stated his belief that al-Quran is the word form Allah (kalam) that is not a creature. AlQuran was sent down to the prophets and His messenger, Muhammad s.a.w (Muhammad 1996,ms.26). this belief is equal to Ahli Sunnah Wal Jamaah that agreed with the above statement. (Ibn Abi al-Iz, 1997).

Rasulullah s.a.w, highlighted about this issue. The faith towards Prophet Muhammad s.a.w demand all the followers to have faith in all the news brought by him and not allowed to reject the truth 
INTERNATIONAL JOURNAL OF ACADEMIC RESEARCH IN BUSINESS AND SOCIAL SCIENCES Vol. 8, No. 11, Nov, 2018, E-ISSN: 2222-6990 @ 2018 HRMARS

comes from the messenger. (Muhammad 2009:389). This one was emphasized by Rasulullah s.a.w which means;

Everyone from my nation will enter Paradise except those who refuse They said, "O Messenger of Allah, who will refuse?" The Prophet said, "Whoever obeys me enters Paradise and whoever disobeys me has refused."(al-Bukhari, 2000)

Mankind are ordered to accept all news brought by the prophet either he brings of news about death, the favour or punishment of the grave,day of resurrection, mahsyar, the sun will be brought close to human in mahsyar, the scale to account the deeds, having the scroll of deeds, haud or well that will be the source of drink for all believers. Other than that, man also need to believe in the Sirat Bridge which will be corssed by the believers according to his their level. (al-Najdiy, 1996).

This statement visibly shows that his belief towards those matters is harmonizing with the belief of ahli sunnah wal jamaah. This can be seen from Ibn Abi al-Izz's (1997) statement which he said that it is compulsory to have faith in all news said by Rasulullah s.a.w and to obey it without any opposition. Another thing that should be faith in is intercession (syafaat). In this matter, Muhammad Ibn Abdul Wahhab (al-Najdiy 1996) said, Rasulullah s.a.w is the first individu to intercede for the people and to accept for the intercession. Intercession will only happen only by the decreed of Allah. As He mentioned in surah al-Ambiya, verse 28:

Meaning:"....and they cannot intercede except on behalf of one whom He approves". In al-Baqarah, verse 255, Allah said :

Meaning: "and they encompass not a thing of His knowledge except for what He wills". Believe in intercession is also one of the condition that meet the teaching of Islamic akidah. In this affair, Ibn Abi al-Iz (1997) stated that Ahli Sunnah put their faith towards the intercession.

Regarding to the existence of the paradise and the fire, he have the faith in both. The heaven and the hell are exist ad it is among the creatures of Allah that are permanent (al-Najdiy 1996). According to al-Ajurriy (1992) the heaven and the fire was created before the existence of Adam and Eve a.s. The proof for this explanation is based on what has been said by Allah in surah al-Baqarah, verse 35:

Meaning:" And We said, "O Adam, dwell, you and your wife, in Paradise and eat therefrom in [ease and] abundance from wherever you will. But do not approach this tree, lest you be among the wrongdoers."

He also thinks that believers will be able to see Allah in the best shape that is suit with his greatness in the hereafter (Muhammad, 1996). This view is match with hadith which was narrated by Muslim (2000) with the narrative genealogy, from Suhaib r.a, stated:"Rasulullah s.a.w said which means:

When the people of Paradise enter Paradise, Allah-may He be blessed and exalted-will say: 'Do you want anything more?' They will say: Have You not made our faces bright? Have You not admitted us to Paradise and saved us from Hell?' Then the veil will be removed and they will not be given anything more beloved to them than looking at their Lord, may He be glorified and exalted."

\section{The Concept of Tawhid According to Muhammad Ibn Abd Al-Wahhab}

Tawhid is his priority in his preaches. Hence, he wrote a book entitled Kitab al-Tawhid. He explained that human and jinns are ceated in order to worship Allah s.w.t. Allah did mentioned in surah alDhariyat, verse 56: 
INTERNATIONAL JOURNAL OF ACADEMIC RESEARCH IN BUSINESS AND SOCIAL SCIENCES Vol. 8, No. 11, Nov, 2018, E-ISSN: 2222-6990 @ 2018 HRMARS

Meaning:" And I (Allah) created not the jinns and humans except they should worship Me (Alone)."

He also quoted what Allah s.w.t has stated in surah al-Nahl, verse 36:

Meaning :And We certainly sent into every nation a messenger, [saying], "Worship Allah and avoid Taghut." And among them were those whom Allah guided, and among them were those upon whom error was [deservedly] decreed. So proceed through the earth and observe how was the end of the deniers.

Allah s.w.t also said in surah al-Nisa', verse 36:

Meaning: "And be servants to Allah and do not associate anything with Him.".

He concluded that in the context of tawhid, human and jinns are created by Allah s.w.t to wroship Him alone. For the purpose of tawhid, Allah has then sent down all prophets and messenger. All of the prophets and messenger aim for the same thing in their preach (al-Wahhab, 2009).

Furtheremore, he, in (2009) said that believe in the oneness of Allah only can be completed when it is followed by rejecting to worship other things other that Allah or also known as Thaghut Allah s.w.t stated in surah al-Baqarah, verse 256:

Meaning: "There is no compulsion in the religion; right-mindedness has already been evidently (distinct) from misguidance. So whoever disbelieves in the Taghut (i.e. false gods, idols, devils and seducers) and believes in Allah, then he has already upheld fast the most binding Grip, with no disjunction (ever); and Allah is Ever-Hearing, Ever-Knowing.".

He then added that Tawhid is a thing that opposite to syirk. Anybody who associate Allah with something else means that they are no longer believe in the oneness of Allah. On the other hand, ones that truly believe in the oneness of Allah will never worship any other things except Him. Hence, syirk has been categorized as the most heinous sins which leads to doom with no hope of redemption, and if a person dies in this state he will abide in Hell for all eternity. Muhammad Ibn Abd al-Wahhab took out statement form al-Quran to explain further about this. Allah s.w.t said in surah al-Anám, verse 151-153:

Meaning:" Say, "Come, I will recite what your Lord has prohibited to you. [He commands] that you not associate anything with Him, and to parents, good treatment, and do not kill your children out of poverty; We will provide for you and them. And do not approach immoralities - what is apparent of them and what is concealed. And do not kill the soul which Allah has forbidden [to be killed] except by [legal] right. This has He instructed you that you may use reason."

"And do not approach the orphan's property except in a way that is best until he reaches maturity. And give full measure and weight in justice. We do not charge any soul except [with that within] its capacity"

In the above verses, the prohibition for syrik or associating Allah s.w.t with something else was placed as the greatest of these sins as compared to other sins such as disobey parents, killing the child, approaching adultery, killing a soul whom Allah has forbidden us to kill, except in cases dictated by Islamic law, and consuming orphans' wealth.

In addition, as concerned to the concept of Tawhid, Muhammad Ibn Abd al-Wahhab explained that there are three things that should be realized by a Muslim. First and foremost, Allah s.w.t is the creator of human being, He has given sustenance to them, and the most essential thing is Allah s.w.t has sent down Prophet Muhammad s.a.w. Whoever obeys him will be promised paradise and 
INTERNATIONAL JOURNAL OF ACADEMIC RESEARCH IN BUSINESS AND SOCIAL SCIENCES Vol. 8, No. 11, Nov, 2018, E-ISSN: 2222-6990 @ 2018 HRMARS

whoever disobeys him will be send to hell. This matter was emphasized by Allah s.w.t in surah alMuzammil verse15-16:

Meaning: "Indeed, We have sent to you a Messenger as a witness upon you just as We sent to Pharaoh a messenger. But Pharaoh disobeyed Our Messenger, so We seized him with a terrible seizing."

Secondly, Allah will no forgive anyone who worship things other than Him. This affair was stressed by Allah in surah al-Jin:

Meaning:" And that the mosques belong to Allah; so do not invoke, along with Allah, anyone.". Thirdly, whoever obeys Allah and his messenger should not follow those unbelivers who against it although they are among their family. Regarding to this matter, Allah s.w.t said in surah al-Mujadalah, ayat 22:

Meaning:": You will not find any people who believe in Allah and the Last Day having affection for the ones who contravene Allah and His Messenger, even if they were their fathers, or their sons, or their brothers, or their kinsmen.".

He then concluded that the biggest command given Allah is Tawhid which one should witness the oneness of Allah in worshipping Him. Meanwhile, the most prohibited thing is Syirk which associating Allah with something else. Allah s.w.t stated in surah al-Nisa'verse36:

Meaning:" And be servants to Allah and do not associate anything with Him. ". (Usul al-Thalathah, 3-4).

Its quite interesting when Muhammad Ibn Abd al-Wahhab (2009) explained about the things that should be practiced by those who belief only in Allah, which they should pray solely to Allah and not other things, asking for help through the good practices, asking protection from Allah the almighty, only permissible to swear an oath by one of the beautiful names of Allah and strongly hold onto Rasulullah's sunnah while visiting the grave. They explained in details of each and everything thing. He also give attention to things related to Syirk in discussing the probelm in tawhid. Syirk is the grave sin because Allah s.w.t will not excuse it without repentance. However, the forgiveness towards other sins other than Syirk is based on Allah s.w.t wills. He has the power to forgive or to give punishment (2009). Allah has said in surah al-Nisa', verse 48:

Meaning: "Verily Allah does not forgive that anything should be associated with Him, and forgives what is besides that to whom He Pleases; and whoever associate (aught) with Allah, has indeed devised a great sin.".

Therefore, syirk has been categorized as a great sin as mentioned by Allah in surah Luqman verse 13:

Meaning:" And [mention, O Muhammad], when Luqman said to his son while he was instructing him, "O my son, do not associate [anything] with Allah. Indeed, association [with him] is great injustice."

\section{Distribution of Tawhid}

Form Muhammad Ibn Abd al-Wahhab's ijtihad, he succeeded in putting forward the new concept in Tawhid distribution. It is a positive development in the knowledge of Islamic aqidah. He then divided tawhid into two main parts (al-Ábud, 2006). First is ,tawhid al-Ilmiy al-Khabriy that consists of Tawhid al-Rububiyah and Tawhid al-Asmaa wa al-Sifaat. Secondly, tawhid al-Talabiy al-Iradiy or best known as Tawhid al-Uluhiyyah. In short, tawhid was divided into three main parts which are al-Rububiyah, 
al-Asma wa al-Sifaat and al-Uluhiyyah. This distribution aims to ease someone to understand the meaning of tawhid. Indeed, this dissemination is not exist during Rasulullah s.a.w, and his companions' time, tabiin and tabi'al-Tabi'in. However, with Abd al-Wahhab's expertise and the inspiration given Allah, he able to find that concept and it was the new contribution to the knowledge of Islamic aqidah. In this state, it is as the same level as the development of other Islamic knowledge such as the knowledge in usul al-Figh, ulum al-Hadith, usul al-Tafsir, Arabic language and so on.

There are Islamic scholars of al-Salaf which made the move to study and write about this akidah including those who discussed about tawhid. Hammad Ibn Salamah (m167H) wrote a book related to akidah entitled al-Sifaat. This masterpiece was among the earliest (al-Abd al-Karim ,2005). Ibn Farrukh ( $\mathrm{m} 175 \mathrm{H})$ composed book of akidah entitled al-Rad ála ahl al-Bida'ah. Besides him, Imam Malik ibn Anas $(\mathrm{m} 179 \mathrm{H})$ also gave contribution that produce a masterpiece which the title is al-Qadr wa alRad Ála al-Qadariyah. In addition, Abd al-Rahman Ibn al-Qasim ( $\mathrm{m} 191 \mathrm{H})$ is also involved with his piece of art called Risalah fi al-Sunnah. Other scholars that devoted in this field is Abu Ubayd al-Qasim Ibn Sallam $(\mathrm{m} 224 \mathrm{H})$ that created a writing with tagged as al-Iman. Throughout the research done by alAbd al-Karim (2005), which estimated to be between 100 Hijrah up to $600 \mathrm{Hijrah}$, there are about 334 books written regarding to akidah based on the manhaj of al-Salaf. This fact shows that the discussion in Islamic akidah is continuous and develop rapidly until now. This including the contribution of art belongs to Muhammad Ibn Abd al-Wahhab that died on $1285 \mathrm{Hij}$ rah. The subscription of Muhammad Ibn Abd al-Wahhab is the continuity of the contributions from the previous scholars.

This Tawhid is the main focus of Muhammad Ibn Abd al-Wahhab in his preach. During his time, there are numbers of belief and practices of khufarat. Hence, he actively has risen agaisnt the falsehood that aroused. His main purpose is to elimiate things related to syirk which lingering in community at that time. (Abd al-Halim Mahmud, 1981:61-61).

\section{Tawhid Al-Ululhiyyah}

The concept of this tawhid is based on what has been stated by Allah s.w.t in surah al-Dhariyat, verse 56:

Meaning:" I have only created Jinns and men, that they may serve Me."

According to (Muallafat al-Syekh 2011,7: 42) this type of tawhid means to perform ibadah sincerely because of Allah and not because of the creature, since the word Ilah in Arabic language that means 'diety' or 'god' to be worshipped and obeyed in ibadah. In other words, it is to say that to worship only Allah s.w.t the Almighty and do not associate Him while worshipping, either the angels, righteous people, prophets and so on (Muallafat al-Syekh 2011, 11:64). This Tawhid make a person a Muslim. It was built based on the sincerity because of Allah in performing ibadah including in resignations, loves, fears, hopes and so on. (al-Muhsin al-Badr 2009:6). Allah mentioned in surah al-Fatihah verse 5:

Meaning:" You alone we worship and from You alone we seek help (and may we always).". Muhsin al-Badr 2009:06).

Tauhid Al-Uluhiyyah is the reasons Allah has created humans and jins. Allah said in surah Dhariyat, verse 56:

Meaning: "And I created the jinns and men, only for them to worship Me. ". 
INTERNATIONAL JOURNAL OF ACADEMIC RESEARCH IN BUSINESS AND SOCIAL SCIENCES

Vol. 8, No. 11, Nov, 2018, E-ISSN: 2222-6990 C 2018 HRMARS

This tawhid also the reason Allah sent down the prophets to invite people towards tawhid and stay away from syirk. Allah stated in surah al-Nahl, verse 36:

Meaning: "And certainly, We have raised (brought to life, charged with a duty) in every nation a Messenger. For them to become servants to Allah and avoid Tâgût (human and jinn Satans)."

Allah then sent down the holy books to explain further about this tawhid. Allah said in surah al-Hadid verse 25:

Meaning: 'We have already sent Our messengers with clear evidences and sent down with them the Scripture and the balance that the people may maintain [their affairs] in justice. "

Tawhid Al-Uluhiyyah is the first and the last thing in religion. Rasulullah s.a.w. said which means:

"so call them to testify there is no God but Allah and I am the Messenger of Allah. . (Al-Bukhari 2000; Muslim 2000).

He continued:" He who dies while knowing (fully well) that there is none worthy of worship (in truth) but Allah shall enter Paradise." (Muslim 2000).

Tawhid Uluhiyyah is the first thing in dakwah. This can be proven when Ini Rasulullah s.a.w sent Muaz to Yemen for preaching purposes, the prophet said:

Verily, you are coming to a people among the people of the Book, so call them to testify there is no God but Allah and I am the Messenger of Allah. (al-Bukhariy 2000).

\section{Syirk Things That Oppose Tawhid}

Syirk towards Allah will cause all the rewards from someone's practice to fall and dismissed, alNajdiy 1996: 06). There are many prove from al-Quran which explain about this matter Allah said in surah al-Zumar,verse 65:

Meaning: And it was already revealed to you and to those before you that if you should associate [anything] with Allah, your work would surely become worthless, and you would surely be among the losers."

Allah also said in surah al-Nisa', verse 116:

Meaning: "Indeed, Allah does not forgive association with Him, but He forgives what is less than that for whom He wills. And he who associates others with Allah has certainly gone far astray.". Allah s.w.t uttered in surah al-Maidah, verse 72: 
INTERNATIONAL JOURNAL OF ACADEMIC RESEARCH IN BUSINESS AND SOCIAL SCIENCES Vol. 8, No. 11, Nov, 2018, E-ISSN: 2222-6990 @ 2018 HRMARS

Meaning:"They have certainly disbelieved who say, "Allah is the Messiah, the son of Mary" while the Messiah has said, "O Children of Israel, worship Allah, my Lord and your Lord." Indeed, he who associates others with Allah - Allah has forbidden him Paradise, and his refuge is the Fire. And there are not for the wrongdoers any helpers."

Believing in any other creatures that able to give benefits and harm other than Allah is among syrik practices that cancel off all the deeds. This belief is opposite to what Allah has said in surah Yunus, verse 107:

Meaning "And if Allah should touch you with adversity, there is no remover of it except Him; and if He intends for you good, then there is no repeller of His bounty. He causes it to reach whom He wills of His servants. And He is the Forgiving, the Merciful."

Worship other than Allah, pray, trust, prohibited what is allowed and vice versa can be categorized in this type of syirk(al-Abud 2006:8-10).

\section{Tawhid Al-Rububiyyah}

The definition of Tawhid is declaration of belief in the oneness of God as the creator of this entire universe, Allah also as the administrator of the whole planet. Someone that believe in this tawhid is not yet a muslim. This is because the non-believers also believe that thi universe was created by God as claimed by the other Muslims. Allah s.w.t mentioned about it in surah Yunus, verse 31:

Meaning:" Say, "Who provides for you from the heaven and the earth? Or who controls hearing and sight and who brings the living out of the dead and brings the dead out of the living and who arranges [every] matter?" They will say, "Allah," so say, "Then will you not fear Him?" (Muallafat alSyekh 2011,7: 42).

Recognition of Allah s.w.t as the creator of this world is not enough to make someone a Muslim (alBadr, 2009). It should be proven by obeying Allah and to perform what have been ordered by Him and leave what are phohibited. Disbelievers however did not apply this. Ibn Abi al-Izz (1997) explained that the reality of this tawhid not make it possible for a person to be called as muslim. Ibn Abbas, Ikramah and Mujahid also agreed with this opinion (al-Tabariy, 2000).

\section{Tawhid Al-Asma Wa Al-Sifaat}

According to Muhammad Ibn Abd al-Wahhab (al-Najdiy, 2006) tawhid al-Asma'wa al-Sifaat fall in usuluddin knowledge. With respect to that, its compulsory to have faith in everything stated in AlQuran dand al-Sunnah regarding to the names and attributes of Allah. the statement for faith is based on what has been said by Allah s.w.t in surah al-Araf, verse 180:

Meaning: "And to Allah belong the best names, so invoke Him by them. And leave [the company of] those who practice deviation concerning His names. They will be recompensed for what they have been doing."

The above verse explained about the three foundations related to tawhid al-Asma wa al-Sifaat. First of all, have faith in the name of Allah, that all His name is good. secondly, say good names belongs to Allah while reciting prayers. Thirdly, keep away from unbelievers (al-Asyqar, 1994). According to alKhattabiy the deviation in this matter is does not believe in the attributes of that has been mentioned by Him in the al-Quran (Hamadah, 2009). 
Revealation is needed in order to know the truth of names and attributes of Allah. This is because it deals with unseen things. Humans will never be able to know Allah by just relying only to the mind. The knowledge about this tawhid cannot be based on guessing. Hence, Allah stated in surah al-Isra', verse 36:

Meaning:" And do not pursue that of which you have no knowledge. Indeed, the hearing, the sight and the heart - about all those [one] will be questioned.".

The above verse shows the prohibition to talk without knowledge. Mans will be resposible for each and everything done by them. Hence, any opinion or views that come without knowledge will be punish with the specific punishment.

No one would ever know the reality of this Tawhid except Allah s.w.t and Rasulullah s.a.w. Therefore, al-Quran dan al-Sunnah should be taken as the main reference to understand this tawhid (al-Asyqar, 1994).

\section{Method of Faith in This Tawhid}

Belief in the Tawhid of Allah's names and attributes has been technically set in al-Quran dan alSunnah. Having faith that His names and attributes cannot be substitutes with any other creatures. Believe that The attributes of Allah Almighty bear no resemblance whatsoever to any creatures attributes. His names and attributes are in a manner that suits His majesty. (al-Najdiy 1996:13). This has been stated by Allah insurah al-Syuraa, verse 11:

Meaning: "There is nothing like unto Him, and He is the Hearing, the Seeing.".

According to Ibn al-Qayyim, the above verse explained that Allah s.w.t denied that His attributes didnt match with any other thing, instead Allah said that He can listen and see (Sayyid Muhammad, 1993). Nuáim Ibn Hammad, who was a teacher of al-Bukhariy said that anybody who substitute Allah with other creature, hence he or she is considered as a non-believer. The same thing happen to those who rejecting the attributes of Allah. He then added that one is not considered substituting Allah with any other creature if they describe Him with what He has desribed Himself. (al-Najdiy, 1996).

Hence, Muhammad Ibn Abd al-Wahhab technically set all the names and attributes of Allah like what have been stated in al-Quran dan al-Sunnah. He believed that those names and attributes of Him in a manner that suits His majesty which cannot be substitute with the characteristic of any creatures. For example, Allah said in surah Taha, verse 5:

Meaning:" The Most Merciful [who is] above the Throne established.". About the eyes, in surah Taha, verse 39:

Meaning :"And I bestowed upon you love from Me that you would be brought up under My eye.". In surah Taha, verse 46:

Meaning:" [ Allah ] said, "Fear not. Indeed, I am with you both; I hear and I see.". Allah stated in surah al-Maidah, verse 64:

Meaning:" Rather, both His hands are extended". In surah Sad ayat 75, Allah mentioned:

Meaning: " [ Allah ] said, "O Iblees, what prevented you from prostrating to that which I created with My hands?

All the above verses explained about istiwa, eyes, listening, seeing and hand. All those attributes are not the same as the characteristic belongs to any creatures. Instead, it is only suit the greatness of 
Allah the Almighty. Allah Almighty ascribed Himslef as all hearing, all seeing, loving, merciful, hence the same apply to the attributes like hand, eyes, istiwa dan so on. There are no problems arise to equalize Allah's attributes with the characteristic of creatures.

The Method to understandand belief in the names and attributes of Allah matched the method used by al-Salaf al-Soleh. This can be proven through their masterpiece. Imam al-Dar al-Qutniy (m 385H) wrote a book entitled Kitab al-Sifat, Imam al-Ajurriy $(\mathrm{m} \mathrm{360H}, 1992)$ wrote a book named al-Syariah, while Imam Ibn Khuzaimah $(\mathrm{m} 311 \mathrm{H}, 1998)$ wrote Kitab al-Tawhid wa Ithbaat Sifaat al-Rab. Imam Ibn Mandah (m. 395H, 2002), al-Bayhaqiy (1993)also one of the person that contributed in the writing, al-Lalikaiy ( $\mathrm{m} \mathrm{417H}, 1995)$ with the book titled Syarh Usul Iktikad Ahl Sunnah wal Jamaah, Abu alQasim al-Asbahaniy (m. 535H, 1999) with his masterpiece, al-Hujjah, Imam al-Darimiy (m. 255H, 1988) with his wriitng known as al-Rad Ála al-Jahmiyyah. Imam Ahmad Ibn Hanbal (m. 241H, 1426H) with his piece of art which known as al-Rad ala al-Zanadiqah wa al-Jahmiyyah. Ibn Abi Asim (m. 287H,1998) wrote kitab al-Sunnah. Abu Uthman al-Sabuniy (m. 449H, 2007), with an art called Akidah al-Salaf wa Ashab al-Hadith. Ibn Battah's (2005) book, al-Ibanah al-Kubra.

\section{Tawhid Concept According to Al-Salaf Al-Soleh}

Tawhid according to al-Salaf is referring to the meaning of syahadah La Ilaha Illallah, Muhammadur Rasulullah verse. Whoever dies knowing that there is no one worthy of worship except Allah shall enter His paradise. (al-Ajurriy, 1992). Al-Salaf scholars used the word faith to explain the meaning of tawhid.In this matter, al-Ajurriy (1992) narrated from Abu Hurayrah r.a, Rasulullah s.a.w said:

Iman has over seventy branches or or over sixty branches, the uppermost of which is the declaration La Ilaha Illallah, and the least of which is the removal of harmful object from the road, and modesty is a branch of iman. (Muttaqun alaihi).

Imam al-Syafie (al-Anqariy 2001:31) said that he asked Imam Malik about the meaning of tawhid, then Iman Malik explained the meaning of tawhid by quoted a hadith which means:

"I have been commanded to fight the people until they testify that there is no deity worthy of worship except Allah and that Muhammad is the Messenger of Allah".

Ibn Suraij (al-Anqariy 2001:32) is one of the famous Islamic figure in mazhab al-Syafie explained that tawhid in expert and Muslimin's side is La llaha Ilallah and Muhammad is His messenger

Another well known icon in mazhab al-Syafie is Uthman al-Darimiy explained the exact meaning of tawhid is the utteration La Ilaha Ilallah Wadahu La Syarikalahu (al-Anqariy 2001:32)

It means, belief in allah Allah and His Oneness and do not associate Him with any other thing. This thing was stressed by Allah in surah al-lkhlas ayat 1-4:

Meaning:" Say: "He is Allah, the One and Unique, Allah, Who is in need of none and of Whom all are in need. He neither begot any nor was He begotten, and none is comparable to Him."

Related to tawhid al-Rububiyah, imam Ibn Battah (2005) stated that having faith in Allah is belief in rububiyyah, adhered to Him in ubudiyah and and justify him for what is said, what is commanded and what is forbidden.

\section{Discussion}

Based on the literature analysis, Muhammad Ibn Abdul Wahhab is a person that has a wide background of Islamic education. His mastery in memorizing is a prove against his power of reasoning 
in thinking effectively. The ability to memorize al-Quran also is one of the proof that shows the purity of heart and mind. If someone is able to memorize al-Quran and get attached to it, hence it means that all the matters related to religion has been understood by him. His understanding towards the content of al-Quran increases when he later on study the meaning of al-Quran. His strong understanding of religion then was supported by his ability to master the hadith that he had learnt. In addition, he also known Arabic language very well as it was his mother tongue. His experienced to migrate for a place to another places to boost up his knowledge also is one of the important factors that help him to shape the deep understanding about the religious life. The background of his teachers whom are the scholars seems to be extremely essential in shaping his deep understanding in religion as well as a great influence towards building his personality.

Through the literature analysis, Muhammad Ibn Abdul Wahhab hold firmly onto the Islamic akidah which based on the al-Quran, al-Sunnah and ljma. This can be identified through the words from his own art work. Al-Quran and al-Sunnah is the prime source in akidah. Meanwhile, the the roles of ijma and ahli sunnah's arguements are to help in streghtening it. However, it doesn't mean that he rejected the role of mind in understanding the akidah. However, the arguement of the mind should match the main source. He strongly holds to the six pillars of faith. His faith towards these pillars suit the faith contained in al-Quran dan al-Sunnah. Every details that related to the six pillars of were fully believed. This includes the favor and punishment in the grave, resurrection, mahsyar, haud, mizan, the fire, the heaven and so on.

According to the akidah tauhid, he defined it as the execution of the worship of a servant towards the one and only Allah s.w.t without associating it with anything else. His view then been supported with numbers of the truth al-Quran and al-Sunnah verses as well as the statements from the previous scholars. He sees tauhid as the main reason for Allah s.w.t. to create mans and jinns. All the prophets was sent by Allah to his people aiming to invite them to belief in the oneness of Allah s.w.t. According to his writing, Muhammad Ibn Abdul Wahhab make tauhid as the aim for his preach. Hence, he actively and aggressively put effort to eliminate the syirk beliefs and practices in his community.

As a reformist, he beliau discuss about tauhid in details with more interesting way. Based on his understanding about the religion, Muhammad Ibn Abdul Wahhab has divided tauhid into three parts which are al-Uluhiyyah, al-Rububiyyah and al-Asma wa al-Sifat. These separation aiming to facilitate people in understanding about the tauhid. Tauhid Uluhiyyah refers to the loyalty of a servant in performing all the practices that has been set by Allah s.w.t without associating Him with any other things. Tauhid Rububiyyah on the other side of the coin means believe that Allah s.w.t is the creator and sustainer of this universe which has no other creator other than Him. Meanwhile, tauhid al-Asma wa al-Sifat or the names and attributes is believe that Allah s.w.t possess the great names and attributes. His attributes is absolutely different with other creatures although some of them might have it too. For example, the attributes of generous and loving. Although human also have that kind of characteristics, but theirs are very limited. The attributes belongs to Allah are very wide and there is no comparison to it.

Muhammad Ibn Abdul Wahab also emphasized the danger and the grave sin of syirk. Syrik to Allah will leads to doom with no hope of redemption if a person dies before they could repent. Since this is a grave sin, hence he totally against any practices that related to syirik. For example, pray to other 
things than Allah, believe in amulets as the shield to human being, believe in the human's fate that determined by the owl, practice the spell in medical, whitchcraft and etc.

The comparison done found that the akidah tauhid of Muhammad Ibn Abdul Wahab is parallel to the tauhid of al-Salaf al-Soleh scholars. This can be proven through the facts in discussion related to tauhid. For instance, related to the purpose of preach belongs to prophets which to invite human to tauhid. This thing was emphasized by al-Salaf scholars such asi al-Ajurriy, al-Lalikaiy. The same thing happened for the tauhid of names and attributes of Allah which shows that the discusssion from Muhammad ibn Abdul Wahhab matched the discussion done by the al-Salaf scholars such as Imam Ibn Khuzaimah, Ibn Manddah, al-Ajurriy, al-Lalikaiy, al-Bayhaqiy.

The comparison done for both foudation of belief between Muhammad Ibn Abdul Wahab's and alsalaf scholars shows that they are same. It means that he is in the right path. This fact is the proof that he does not belongs to the groups that described Allah as a creature.

\section{Findings}

The research done found that Muhammad Ibn Abd al-Wahhab is a religious reformer. In other words, he is a mujadid (reformer). This is proven through the impact of da'wah (preach) that has been carried out by him to suppress khurafat and syrik things which has long been rooted in his society. This study also shows that his preach was held according to the right path of al-Salaf al-Soleh. In the context of Islamic akidah, he holds onto the methods brought by Imam Ahmad Ibn Hanbal prove that Muhammad Ibn Abd al-Wahhab strongly hold onto the foundation of faith, including his confidence about the favor and punishment of the grave.

Aqidah is the foundation that was given a priority by him in his preach. This can be seen in his explanation regarding to the aim of prophets to invite their people towards the akidah tawhid and to stay away from syirk. It is the great sin which will not be forgiven unless with repentance. The syirk practice will cancell out all human's good deeds and erased them from the record of deeds . if one died in syirk hence he will abide in Hell for all eternity.

This study confirmed that the Tawhid concept of Muhammad Ibn Abd al-Wahhab is based on alQuran dan al-Sunnah. He considered the views from al-Salaf scholars such as Imam Ahmad, Ibn Taymiyyah, Ibn al-Qayyim and others as the reference in akidah. According to him, tawhid means to believe only in the oneness of Allah s.w.t in performing ibadah. He said that Tawhid can be divided into three mian parts which are tawhid al-Rububiyyah, tawhid al-Asma wa al-Sifaat and tawhid alUluhiyyah. Tawhid al-Rububiyyah referring to the belief that this universe was created and maintaned by Allah the Almighty. Meanwhile, tawhid al-Asma wa al-Sifaat is related to the faith that Allah has the great names and attributes that nothing likes whatever Him. Tawhid al-Uluhiyyah is to single out Allah alone in worshipping and to abandon worship of others besides Him.

The fidings also show beyond doubt that his method of uderstanding in interpreting the names and attributes of Allah meets the requiremet and methods used by al-Salaf al-Soleh scholars. He strongly believe in the al-Quran and al-Sunnah that explain about the names and attributes of Allah. In reality, the attributes of Allah is totally different from the nature of any creatures. There are various Quranic verses with clear evidences which explain about His name and attributes. Indeed, the belief held by him is parallel to the teaching of al-Salaf al-Soleh. This thing can be proven through the reading of sacred books such as kitab al-Sifaat, Kitab al-Syariáh, Kitab al-Rad ala Jahmiyyah and etc. 
INTERNATIONAL JOURNAL OF ACADEMIC RESEARCH IN BUSINESS AND SOCIAL SCIENCES

Vol. 8, No. 11, Nov, 2018, E-ISSN: 2222-6990 @ 2018 HRMARS

Therefore, all the scattered rumors claiming he is unbeliever and has gone astray are not true at all. Hence, JAKIM has issued a statement which confirms that the teaching brought by Muhammad Ibn Abd al-Wahhab is in the right path.

\section{Conclusion}

Throughout the research that has been conducted it is obviously proven that Muhammad Ibn Abd alWahhab is a religious reformer. He brought the tawhid based on al-Quran dan alSunnah. Tawhid is considered as one of the reason either one's practice will be accepted by Allah s.w $\mathrm{t}$ or not.Tawhid can be divided into three parts. This tawhid method that based on al-Quran and alSunnah has rapidly expanded and began to be understood by the community. Muhammad Ibn Abd al-Wahhab's belief in the tawhid of names and attributes of Allah is parallel to what is believed by alSalaf al-Soleh scholars. They hold onto the verses of al-Quran dan al-Sunnah.

\section{References}

Al-Asyqar. (1994). Asmaa'u Allah wa Sifaatuhu. Jordan: Dar al-Nafais.

Al-Atram. (1991). Iktimad Feqh Dakwah al-Syekh Muhamamad Ibn Abd al-Wahhab Ála al-Kitab alSunnah. Riyad: Universiti al-Imam.

Al-Sabuniy. (2007). Aqidah al-Salaf wa Ashaab al-Hadith. Yamen: Maktabah al-Imam al-Waad'iy.

Al-Abd al-Karim (2005). Tarikh Tadwin al-Akidah al-Salafiyyah. Riyad: Dar al-Sumaiíy.

AlAbud. (2006).Akidah al-Syekh Muhammad Abd al-Wahhab al-Salafiyyah. Madinah: Univ. Islam Madinah.

Al-Badr. (2009). Al-Mukhtasar al-Mufid fi Bayani Dalaili Aqsam al-Tawhid. Kuwait: Maktabah Ibn alQayyim.

Al-Ajurriy. (1992). Al-Syariah. Riyad: Dar al-Salam.

Al-Anqariy. (2001). Aqidah Imam al-Syafie Min Nusus Kalamihi Wa Idahi Ashabihi. Tesis ljazah Doktor Falsafah yang dikemukakan kepada Kuliyyah Dakwah dan Usuluddin, Universiti Ummul Qura, Mekkah, Arab Saudi.

IbnHanbal. (1424H). Al-Rad 'ala al-Jahmiyyah wa al-Zanadiqah. Riyad: Dar al-Thabat.

Abdal-Halim. (1981). Al-Salafiyyah wa Dakwah al-Syekh Muhammad Abd al-Wahhab. Saudi Arabia: Maktabah Ukaz.

Al-Bukhariy. (2000). Sahih al-Bukhariy. Riyad: Dar al-Salam.

Al-Bayhaqiy. (1993). Al-Asmaa'wa al-Sifaat. Jeddah: Maktab al-Sawadiy.

Al-Qutniy. (2005). Kitab al-Sifaat. Riyad: Dar al-Sumay'iy.

Al-Darimiy. (1988). Al-Rad 'ala al-Jahmiyyah. Beirut: al-Maktab al-Islamiy.

FaruqHamadah. (2009). Asmaa Allah al-Husna Fi al-Quran al-Karim wa al-Sunnah

al-Nabawiyyah. Keherah: Dar al-Salam.

IbnKhuzaymah. (1983). Kitab al-Tawhid. Beirut: Dar al-Kutub al-Ilmiyyah.

IbnBattah. (2005). Al-Ibanah al-Kubra. Riyad: Dar al-Rayah.

Al-Asbahniy. (1999). Al-Hujjah fi Bayani al-Mahajjah. Riyad: Dar al-Raayah.

Al-Ilzz. (1997). Syarh al-Aqidah al-Tahawiyyah. Beirut: Muassasah al-Risalah.

Asim. (1998). Al-Sunnah. Riyad: Dar al-Sami'iy. 
INTERNATIONAL JOURNAL OF ACADEMIC RESEARCH IN BUSINESS AND SOCIAL SCIENCES

Vol. 8, No. 11, Nov, 2018, E-ISSN: 2222-6990 C 2018 HRMARS

IbnManda. (2002). Al-Tawhid wa Ma'rifat Asmaillah wa Sifatihi. Beirut: Muasasah al-Risalah. Madinah: Maktabah al-Ulum wa al-Hikam.

IbnKhuzaimah. (1988). Kitab al-Tawhid wa Ithbaat Sifaat al-Rab Azzawajalla. Riyad: Dar al-Rusyd.

I-Lalika'iy. (1995). Syarh Usul Iktiqad ahl al-Sunnah wal Jamaah. Riyad: Dar Tayyibah.

AbdulWahhab. (1999). Al-Usul al-Thalathat wa Adillatuha. Riyad: Maktabah al-Malik Fahd alWataniyah.

AbdulWahhab. (2009). Kitab al-Tawhid. Damaj: Maktabah Imam al-Wadaíy.

IbnMuslim. (2000). Sahih Muslim. Riyad: Dar al-Salam.

Al-Najdiy. (1996). Al-Durar al-Saniyyah fi al-Ajwibati al-Najdiyyah. Saudi Arabia.

Sayyid. (1993). Al-Jami Li Tafsir al-Imam Ibn al-Qayyim al-Jawziy Dammam: Dar Ibn al-Jawziy.

Al-Tabriy (2000). Jami'al-Bayan Án Ayii al-Quran. Arab Saudi: Percetakan al-Malik Fahd.

www.abouasem.net. 2011/3/20. Majmu Muallafaat al-Syekh Muhammad Ibn Abdul Wahhab:

Ijma 'Ala Anna al-Iman Mahalluhu al-Qalb. Anecdotes of the prophet - hikayat 